\section{Value of factor VIII related antigen as a means of demonstrating extramedullary megakaryopoiesis}

\author{
J CROCKER, PJ SMITH Department of \\ Histopathology, East Birmingham Hospital, \\ Bordesley Green East, Birmingham B9 5ST
}

A recurrent problem in diagnostic histopathology is that of detecting foci or infiltrates of extramedullary haemopoiesis, erythropoiesis, or megakaryopoiesis. Such tissue is usually composed of a polymorphic mixture of cells. Only when well differentiated and defined mature megakaryocytes are present may the diagnosis be readily made; even then, however, a further problem arises. When there is a suspicion of Hodgkin's disease, it may be impossible to distinguish clearly between more primitive megakaryocytes and Reed-Sternberg and Hodgkin cells. Clearly, the distinction is of prime importance, whether the suspect infiltrate is in liver, spleen, lymph node, or even the central nervous system. Unfortunately, like Reed-Sternberg cells, megakaryocytes contain immunoglobulin light and heavy chains.'

We have found that immunohistochemical staining for factor VIII related antigen (F VIII RAg) is invaluable. F VIII RAg is synthesised by endothelial cells, ${ }^{2-5}$ but has also been shown ultrastructurally in megakaryocytes. ${ }^{6}$ Mast cells also show activity of the antigen. ${ }^{78}$

Antiserum to F VIII RAg is readily available commercially (for example, from Mercia Brocades Ltd, Weybridge, Surrey, UK). We have found the unlabelled primary antibody peroxidaseantiperoxidase (PAP) technique applied to routinely processed paraffin sections most useful. Rabbit antihuman F VIII RAg is applied to sections at a dilution of $1 / 50$, after trypsinisation to increase sensitivity of the method ${ }^{8}$ and blocking of endogenous peroxidase with $0.1 \%$ hydrochloric acid in methanol. The first stage is followed, as usual, by swine antirabbit immunoglobulin serum, then by rabbit PAP complex. The latter is demonstrated by means of the 3,3-diaminobenzidine reaction. Sections are counterstained in Mayer's haemalum, dehydrated, cleared, and mounted in synthetic medium. In addition to the usual controls the reaction should be "blocked" by means of factor VIII

Accepted for publication 21 February 1984

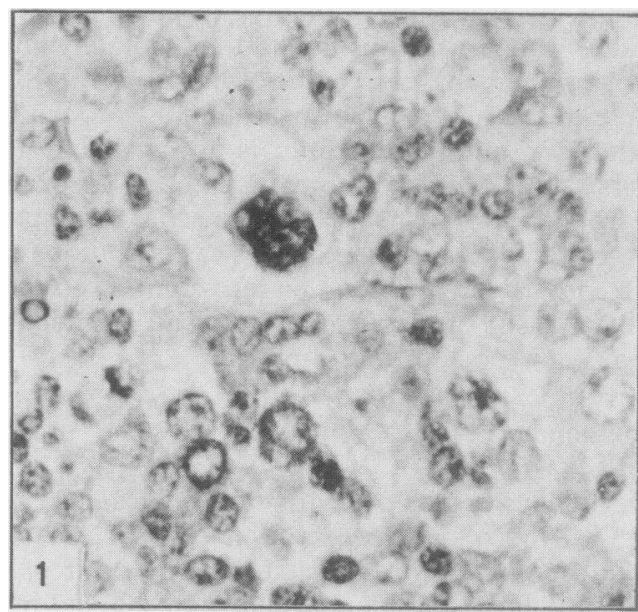

Fig. 1 Field from lymph node showing large cell with lobulate nucleus, resembling a so called "lacunar" cell. Haematoxylin and eosin. $\times 250$.

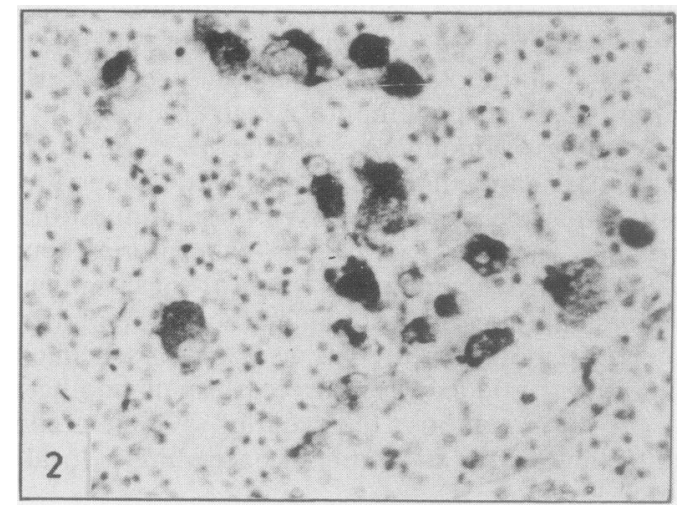

Fig. 2 Field from same node as in Fig. 1, showing many large cells staining positively for F VIII RAg; these are megakaryocytes. PAP method for F VIII RAg; haemalum counterstain. $\times 85$.

(Armour Pharmaceutical Co Ltd, Eastbourne, East Sussex, UK).

Megakaryocytes are strongly stained by this procedure, as is vascular endothelium; these are readily morphologically differentiated. Mast cells are also stained, but these are also distinguished from megakaryocytes by virtue of their highly granular cytoplasm and nuclear size and morphology.

As an example of the value of this technique, Fig 1 shows a lymph node containing large, often bi- or multinucleated cells, the nature of which was obscure. Figs. 2 and 3 show the result of staining for $F$ VIII RAg; megakaryocytes are intensely stained. 


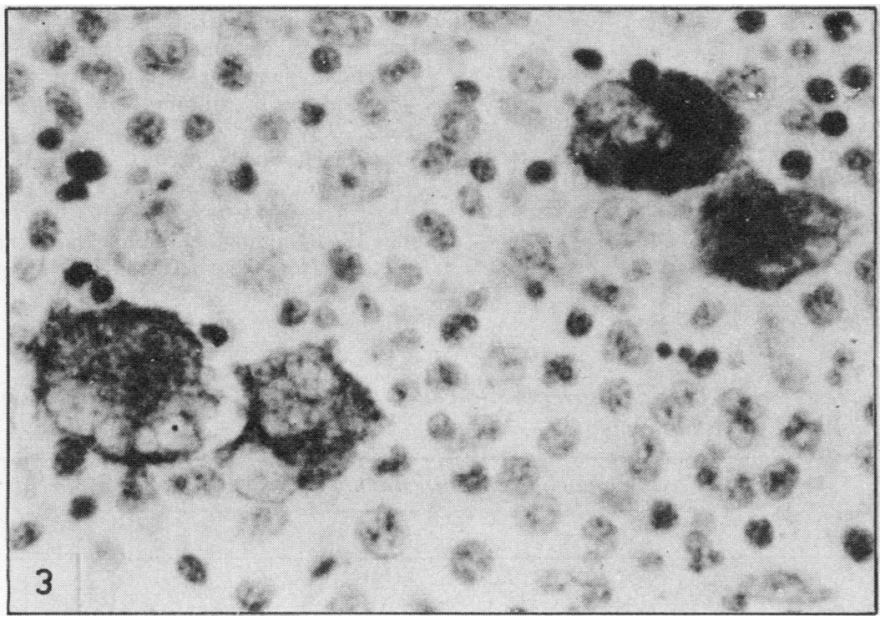

Fig. 3 Four large megakaryoctyes with their cytoplasm staining in a granular pattern for F VIII RAg. PAP method for F VIII RAg; haemalum counterstain. $\times 500$.

The patient was subsequently shown to have florid myelofibrosis, thus accounting for the nodal extramedullary megakaryopoiesis.

In relation to Hodgkin's disease, it is emphasised that Reed-Sternberg and Hodgkin cells are negative for F VIII RAg activity by means of the PAP technique. ${ }^{8}$ Thus we advocate the use of this method as a means of distinguishing these cells from megakaryocytes. Trephine samples of bone marrow, fixed and decalcified in 5\% acetic acid in formalin, are well suited to this reaction and the need for trypsinisation is avoided.'

Although megakaryocytes are negative for the protease cathepsin B and Reed-Sternberg cells are positive, ${ }^{4}$ staining for this enzyme is not helpful in distinguishing the two cell types as the positivity of Reed-Sternberg cells is inconstant. ${ }^{9}$

\section{References}

' Crocker J, Curran RC. Quantitative study of the immunoglobulin-containing cells in trephine samples of bone marrow. J Clin Pathol 1981;34:1080-2.
${ }^{2}$ Hoyer LW, De Los Santos RP, Hoyer JR. Antihaemophilic factor antigen: Localisation in endothelial cells by immunofluorescent microscopy. J Clin Invest 1973;52:273744.

${ }^{3}$ Jaffe EA. Synthesis of factor VIII antigen by cultured human endothelial cells. Ann NY Acad Sci 1973;240:62-9.

4 Jaffe EA. Endothelial cells and the biology of factor VIII. N Engl J Med 1977;296:377-83.

${ }^{5}$ Mukai K, Rosai J, Burgdorf WHC. Localisation of factor VIII related antigen in vascular endothelial cells using an immunoperoxidase method. Am J Surg Pathol 1980;4:273-6.

- Piovella F, Nalli G, Malamani GD, et al. The ultrastructural localisation of factor VIII antigen in human platelets, megakaryocytes and endothelial cells utilizing a ferritin labelled antibody. Br J Haematol 1978;39:209-13.

${ }^{7}$ Kindblom LG. Factor VIII related antigen and mast cells. Acta Pathol Microbiol Immunol Scand 1982;90:437-9.

${ }^{8}$ Crocker J, Smith PJ. Immunohistochemical localisation of factor VIII related antigen in Hodgkin's disease. J Clin Pathol 1984;37:37-44.

' Crocker J, Burnett D, Jones EL. Immunohistochemical demonstration of cathepsin B in the macrophages of benign and malignant lymphoid tissues. J Pathol 1984;87-94.

Requests for reprints to: Dr J Crocker, Department of Histopathology, East Birmingham Hospital, Bordesley Green East, Birmingham B9 5ST, England. 